\title{
Antibiotic utilization in community-A literature review
}

Review Article

\author{
Anil Kumar Sah ${ }^{1}$, D.S Rathore ${ }^{2}$, Kadir Alam ${ }^{3}$, Anup Pradhan ${ }^{4}$ \\ ${ }^{1}$ Lecturer, Department of Pharmacy, Purbanchal University College of Medical and Allied Sciences, Gothgaun, \\ Nepal \\ ${ }^{2}$ Professor, Department of Pharmacy, Goenka College of Pharmacy, Bikaner road, Laxmangarh, Rajasthan, \\ India \\ ${ }^{3}$ Associate Professor, Department of Clinical Pharmacology and Therapeutics, B.P. Koirala Institute of Health \\ Sciences, Dharan, Nepal \\ ${ }^{4}$ Research Director, SunRise University, Alwar, Rajasthan, India
}

Received: 18-01-2019 / Revised: 15-06-2019 / Accepted: 25-08-2019

\begin{abstract}
Antibiotic is major health problem in the developing and developed countries. Appropriate use of antibiotic provides the benefit of cost-effective, clinical therapeutic effect, decreased drug-related toxicity and the development of antibiotic resistance. In Mongolia, around $80 \%$ of antimicrobial drugs are purchased without a prescription from retail pharmacies. In Asian countries, 50-90\% of pharmaceutical medicines transactions are occur in private retail pharmacy mostly in community The literature review was conducted to study the antibiotic utilization in community. Literature review is conducted with the variety of literature from 1994 to 2018. The search was done in Hinari, Google, Google Scholar, PubMed for articles published in English using the keywords "use of antibiotic in community, Antibiotic AND resistance AND community AND developing country AND developed country, Pattern of antibiotic use AND community AND developing AND developed country,survey study on antibiotic use and antibiotic resistances in community, and self-medication antibiotic use. Antibiotic utilization in Latin America from 1997-2007 revealed that use of antibiotic was increased in Peru (70.6\%), Venezuela (43.0\%). Study on irrational use of antibiotic in an urban slum community in Lagos, Nigeria suggested that $63.4 \%$ slum community was found to be non-adherence to the antibiotic therapy. Study from Peshawar, Pakistan on selfmedication with antibiotic suggested most commonly used of antibiotics were amoxicillin/clavulanic acid (45\%), ciprofloxacin (31\%), sulfamethoxazole/ trimethoprim (18\%), and clarithromycin (5\%). Self-medication with antibiotic among dental students in Kathmandu suggested most frequently use of antibiotics were amoxicillin, metronidazole, azithromycin, ciprofloxacin and amoxicillin and clavulanic respectively.Antibiotic resistance patterns of common Gram negative pathogens isolate from urinary tract infection in Ethiopia noted that the resistance rate of E. coli pathogens was high with common antibiotics like tetracycline, ampicillin, amoxicillin and nalidixic acid. Similarly, these pathogens were low resistance with nitrofurantoin, gentamycin and trimethoprimsulfamethoxazole. Conclusively, there were high antibiotic use and resistance which is huge global problem and require special attention.
\end{abstract}

Key word: Antibiotic utilization, Antibiotic resistance, Community, Self-medication

(C) The Author(s). 2019 Open Access. This work is licensed under a Creative Commons Attribution. The full terms of this license are available at our website and incorporate the Creative Commons Attribution. https://creativecommons.org/licenses/by/4.0/

\section{INTRODUCTION}

Rational use of medicines has been defined by World health organization as patient get medication correct to

*Correspondence

Anil Kumar Sah

Lecturer, Department of Pharmacy

Purbanchal University College of Medical

and Allied Sciences, Gothgaun, Nepal.

E-mail: anilsahnp@gmail.com their clinical requirements, in doses that meet their individual needs, for right period of time, and at the lowest price to them and their community.[1]When it comes to irrational use of antibiotics, it adds another risk of antibacterial resistance.

As per WHO define appropriate use of antibiotic as "the cost-effective use of antibiotics, which maximizes clinical therapeutic effect while minimizing both drugrelated toxicity and the development of antibiotic resistance.[2] In developed countries, half of the 
antibiotics consumed in community are considered to be based on incorrect indications and most common indications are viral infections.[3]As per World Health Organization (WHO) definition of drug utilization as the marketing, distribution, prescription and use of drugs in a society, considering it consequences. Either medical, social and economic. [4]Studies suggested self-medication with antibiotic practices is huge problem.[5, 6] In context of developing country, this type of practice can lead to develop antibiotic resistance[7,8,9,] and similarly other context of developed country.[10,11, 12,13, 14] Further, in European countries this types of practice also have high rate.[15]Study suggested community pharmacies dispensed antibiotic without prescription can lead antimicrobial resistance.[16] Antibiotic is major health problem in the developing and developed countries. Hence, the antibiotic was commonly available as over the counter, the over and under uses of antibiotic can leads to antibiotic resistance, drug adverse effect and unnecessary increase health cost. Irrational uses of antibiotic in community to develop resistance of antibiotic, increase of health cost, morbidity and mortality in community. In Mongolia, around $80 \%$ of antimicrobial drugs are purchased without a prescription from retail pharmacies. [16]In Asian countries, $50-90 \%$ of pharmaceutical medicine transactions are prepared in private retail pharmacy.[17,18,19]The literate review was conducted with the objective to identify common antibiotic utilization, antibiotic resistance and problem related to antibiotic. Literature review is conducted with the variety of literature from AD 1994 to AD 2018. The search was done in Hinari, Google, Google Scholar and PubMed published articles in English. Using the keywords "use of antibiotic in community, Antibiotic AND resistance AND community AND developing country AND developed country, Pattern of antibiotic use AND community AND developing AND developed country, Simulated clients survey antibiotic use in community, survey study on antibiotic use and antibiotic resistances in community, and selfmedication antibiotic use".

\section{Antibiotic use in community in developed country}

A study on antibiotic utilization in Latin America from 1997-2007 suggested that use of antibiotic were increased in Peru (70.6\%), Venezuela (43.0\%) while decreased use of antibiotic in Mexico (-2.43 DID; $15.5 \%)$ and Colombia $(-4.10 ;-33.7 \%)$. [20] Another survey study on antimicrobial resistance correlated with use of beta-lactam and macrolides in Europe showed that the beta-lactam and macrolide antibiotic used in highest in the three countries like France 24 DDD/1000 inhabitants/day, Spain 21 DDD/1000 inhabitants/day, Portugal 16 DDD/1000 inhabitants/day for beta lactam and France 6 DDD/1000 inhabitants/day, Spain 5.9 DDD/1000 inhabitants/day, Italy 5.1 DDD/1000 inhabitants/day for macrolides in the Europe. [21] Similarly, another study on antibiotic use in 13 non-EU countries and areas of the WHO European region suggested that increase of inappropriate use of antibiotic ranged from of $15 \cdot 3$ DID in Armenia to $42 \cdot 3$ DID for Turkey. Coamoxiclav was mainly used in Georgia (42.9\% of total antibiotic use) and Turkey $(30.7 \%)$ in the eastern Europe. [22]

\section{Antibiotic use in community in developing country other than Asian country}

Study on pattern and consumption of antibacterial drugs in Jordanian population revealed that less than one half of all antibacterial drugs was dispensed without prescription (46\%) through self-medication (46\%) and pharmacist recommendation (23\%). The study also suggested that the prescribed and nonprescribed (over-the-counter) antibacterial drug was used improperly. [23] Another study on irrational use of antibiotic in an urban slum community in Lagos, Nigeria suggested that $63.4 \%$ slum community was found to be non-adherence to the antibiotic therapy. [24] Study on utilization pattern of antibiotic in Benin adult populations revealed that the most commonly used antibiotics were ampicillin, chloramphenicol, streptomycin, and tetracycline. [25] Studies from Hanoi, Vietnam [26], Benin, Nigeria [25] suggested that commonly used of antibiotic were ampicillin, amoxylline, co-trimoxazol cephalexin in vietnam and erythromycin, gentamicin, and cloxacillin in Nigeria respectively. A survey study on patterns of antibiotic use in a rural community in the Philippines suggested that most frequently use antibiotic were aminopenicillins (29.3\%). anti-tuberculosis agents (15.5\%), natural penicillins (13.9\%). [27] Another study on use and knowledge of antibiotic in three countries Yemen, Saudi Arabia and Uzbekistan suggested that the prevalence of non-prescription use of antibiotic were $48 \%$ in Saudi Arabia and $78 \%$ in Yemen and Uzbekistan. The study also suggested that most common indication of antibiotics were in cough (40\%) and influenza (34\%). [28]

\section{Antibiotic use in community in Asian country}

A study on patterns of prescribing, consumption and dispensing of antibiotics in Chittagong city in Bangladesh revealed that commonly prescribed drugs were azithromycin (30.49\%), cefixim (19.51\%) and ciprofloxacin (15.85\%). However, azithromycin $(22.65 \%)$, ciprofloxacin (20.01\%) and cefixme 
(15.71\%) were sold without prescription from local pharmacy shop. [29] Likewise, the study on prevalence of non-prescription sale of antimicrobial drugs by pharmacies in Bangalore, India suggested that most frequently prescribed drugs were amoxicillin (51.2\%), azithromycin and ciprofloxacin (12.2\% of each). [30] A survey study on use of antibiotic trends in the public and outpatient sectors in New Delhi, India suggested frequently prescribed antibiotic were fluoroquinolone group and extended spectrum penicillin group of drugs at private retailer pharmacy and private clinics. [31]

\section{Self-medication with antibiotic in community in} developing country

A survey study conducted in United Arab Emirates on the incidence of self-medication with antibiotic found $485(56 \%)$ participants used antibiotic in the period the last one years. Most commonly used antibiotic was amoxicillin (46.3\%). [14] Another study conducted in Peshawar in the urban population on self-medication with antibiotic noted that most commonly used of antibiotics were amoxicillin/clavulanic acid (45\%), ciprofloxacin $(31 \%)$, sulfamethoxazole/ trimethoprim (18\%), and clarithromycin (5\%). [32] Similarly, study on self-medication with antibiotics in urban population in Indonesia revealed that amoxicillin, ampicillin, fradiomisin- gramisidin, tetracycline, and ciprofloxacin drugs were commonly used as self-medication for treating the condition like cough, sore throat, headache, and other minor condition. [33]

\section{Self-medication with antibiotic use in community in developed country}

Study on self-medication with antibiotic in Latino communities in the united states revealed that the use of antibiotic was increased in the intervention community. The intervention community was aware about the availability of antibiotic without prescription and consequently influence higher usage of antibiotic.[34] Study on self-medicated in adult Latin American immigrants in Seville suggested that consumption of anti-inflammatory, non-prescription analgesics and antibiotic were found higher in Seville city. [35]Another study of self-medication with antibiotic in Lithuania revealed that most common condition for antibiotic use were tonsillitis, bronchitis, and upper respiratory infections. [36] Study on selfmedication with antibiotics in northern Israel suggested that most frequently use of drugs were penicillin, cephalosporin and macrolide. [37] Another study of self-medication with antibiotics in Cameroon revealed that most commonly use of antibiotic for respiratory tract infections was cotrimoxazole and amoxicillin. [38] Similarly, study on self-medication practices among university students in Turkey suggested most common drugs used by university students were analgesic $39 \%$, antibiotic $36.9 \%$ and cold remedies (24\%) respectively. [39] Likewise, a survey study on self-medication with antibiotic for respiratory tract infection in Poland suggested that most common belief of antibiotic used in majority of infection was influenza and influenza-like illnesses. [40]

\section{Self-medication with antibiotic use in community in Nepal}

A study on self-medication with antibiotic among dental students in Kathmandu suggested that more than two thirds $(81.5 \%)$ of dental students gave history of antibiotic use in the period one year and among them $35.1 \%$ students gave history for self-medication. The study also suggested that most common antibiotics used were amoxicillin,metronidazole,azithromycin, ciprofloxacin and amoxicillin and clavulanic respectively. [41] Similarly, another study of selfmedication with antibiotics among nursing students suggested that amoxicillin, azithromycin and ciprofloxacin antibiotics were frequently used in selfmedication practice for treating in fever, sore throat and rhinitis. [42] Another study of self-medication and non-doctor prescription practice in the western region of Nepal revealed that most common use of drugs were paracetamol, NSAIDs, herbal remedies along with other antimicrobial drugs. [43]

Studies on Antibiotic use in community

\begin{tabular}{|c|c|c|c|c|}
\hline Author's & Country & Main Obj & $\begin{array}{c}\text { Categorization } \\
\text { of antibiotic }\end{array}$ & Main Finding \\
\hline $\begin{array}{l}\text { Zawahi.S } \\
\text {.[44] }\end{array}$ & $\begin{array}{c}\text { Sri } \\
\text { Lanka }\end{array}$ & $\begin{array}{l}\text { To evaluate the } \\
\text { response of community } \\
\text { pharmacy staff to an } \\
\text { antibiotic product } \\
\text { request without a } \\
\text { prescription } \\
\text { To explore possible }\end{array}$ & $\begin{array}{l}\text { Ciprofloxacin } \\
\text { Amoxicillin }\end{array}$ & $\begin{array}{l}\text { - Only } 16 \quad(7 \%) \text { pharmacy staff } \\
\text { recommended the simulated clients to see } \\
\text { a doctor. } \\
\text { Overall, } 61 \% \text { of pharmacies dispensed } \\
\text { antibiotics without a prescription. } \\
\text { The highest dispensed antibiotic was } \\
\text { ciprofloxacin (44/63 requests; } 70 \%) \text { and } \\
\text { the least was amoxicillin }(32 / 62 ; 52 \%)\end{array}$ \\
\hline
\end{tabular}




\begin{tabular}{|c|c|c|c|c|}
\hline & & $\begin{array}{l}\text { factors influencing } \\
\text { such practice }\end{array}$ & & \\
\hline $\begin{array}{l}\text { Chang.J } \\
\text { et al.[45] }\end{array}$ & China & $\begin{array}{l}\text { To quantify sales of } \\
\text { antibiotics without } \\
\text { amedical prescription } \\
\text { and to assess the } \\
\text { quality of pharmacy } \\
\text { services in relation to } \\
\text { the antibiotics sold in } \\
\text { community pharmacies } \\
\text { in urban China. }\end{array}$ & & $\begin{array}{l}\text { - Of } 256 \text { pharmacies, antibiotics were } \\
\text { obtained without a prescription from } \\
55.9 \% \text { (95\% CI: 49.5\%-62.0\%) when } \\
\text { paediatricdiarrhoea was simulated and } \\
\text { from } 77.7 \% \text { (95\% CI: } 72.1 \%-82.7 \%) \\
\text { when adult respiratory infection was } \\
\text { simulated. } \\
\text { About } 83.9 \% \text { and } 66.3 \% \text { antibiotic } \\
\text { dispensed from pharmacy after the } \\
\text { simulated clients requested or insisted in } \\
\text { the case of paediatricdiarrhoea and adult } \\
\text { respiratory infection, respectively. } \\
\text { The performance of pharmacy staff } \\
\text { regarding the provision of information and } \\
\text { advice was unsatisfactory }\end{array}$ \\
\hline $\begin{array}{l}\text { Ansari. } \\
\text { M.[46] }\end{array}$ & Nepal & $\begin{array}{l}\text { To determine the most } \\
\text { commonly dispensed } \\
\text { antibiotic among the } \\
\text { pharmacies located in } \\
\text { and around National } \\
\text { Medical College } \\
\text { Teaching Hospital }\end{array}$ & $\begin{array}{l}\text { Penicillins, } \\
\text { Cephalosporins, } \\
\text { Macrolides, } \\
\text { Fluoroquinolone }\end{array}$ & $\begin{array}{l}\text { - The top } 15 \text { selling antibiotics belonged } \\
\text { to four different groups including } \\
\text { Penicillins, Cephalosporins, Macrolides } \\
\text { and Fluoroquinolones. } \\
\text { Beta lactam antibiotics were the most } \\
\text { selling antibiotics followed by Macrolides } \\
\text { and Fluoroquinolones. }\end{array}$ \\
\hline
\end{tabular}

Access Health Care and Antibiotic in the Community

Health care system in Nepal: Treatment of disease in Nepal is mainly traditional medicine (Ayurveda, unani, homeopathy etc) and modern medical health care system. Usually, there is at least one health facility in each village development committee (VDC), one primary health care center in each electoral constituency, and one hospital at the district level to provide curative services. According to the public health system, services are classified into three i.e. primary, secondary and tertiary level.

Primary level: This level covers female community health volunteers, primary health care outreach clinics, community health units. Service delivery at this level is largely the responsibility of medical officers, health assistants, staff nurses, auxiliary health workers, auxiliary nurse midwives, and female community health volunteers, who provide a range of mostly promotive and preventable services in addition to some curative services.

Secondary level: Secondary-level services are delivered by district hospitals. These are first referral points from the primary-level health facilities and provide inpatient, outpatient, emergency, and comprehensive emergency obstetric and neonatal care services for their target populations.

Tertiary level: Tertiary-level services are provided by zonal, sub regional, regional, and central hospitals. These institutions are second-level referral points for districts and also provide other services in their catchment areas. Central hospitals offer professional training, conduct research, and provide support to the districts.[47]

\section{Common disease in the community}

Common disease accounting in Nepalese community. Among of the common disease, the first rank of disease was Pyrexia of Unknown origin and Headache, second one was Gastritis (APD), Acute Respiratory Infection (Lower Respiratory Tract Infection) and third one was Upper Respiratory Tract Infection.[48]

\section{Access to the antibiotic in the community}

In Nepal, no special mechanism for accessing of antibiotic in community. These antibiotics are supplied and procure as same as of other drugs. There are three mechanisms for accessing of medicine in the 
community i.e Central push system, District level procurement and community drug programmes.

Central push system: Antibiotics have supplied by the logistic management division (LMD) to the government hospital and primary health care facilities. These managements areresponsible for purchasing, supplying to the health units over the country. It has also responsible for distributing antibiotic through push system to all health units.[49]

District level procurement: The district office is also responsible for the procurement and purchase of these antibiotic drugs through tender. All the drugs for the health posts pass through the district office.[49]

Community drug programmes: Community drug programmes CDPs are supported by groupings of organizations, including UNICEF and the Swiss development corporation (SDC). Other partners include GTZ, and others, making this national programme a complex of institutional assemblages. Some financial assistance comes from the World Bank "pool fund".

Procurement is done at the district level. At each district, they identify wholesalers, and this list is given to all the village development committees.[49]

In Nepal, Antibiotic is illegal to buy and sale antibiotic without prescription or over the counter. However, the community pharmacists have to treat patients with these medicine. Several countries is restricted antibiotic to sale as OTC. However in a few countries, antibiotics are legally available as OTC drug such as erythromycin gel 3\% (30gram) (Albania), fusafungin (Czech Republic), bacomycin (Norway), 24-hour dosage of any antibiotic medicines in emergency situations (Romania), antibiotics with local effect (eye and topical preparations) (Serbia and Slovakia), and chloramphenicol eye drops for the treatment of conjunctivitis and azithromycin for the treatment of chlamydia (United Kingdom).[50]

\section{Antimicrobial Resistance in Community}

Studies from India, Pakistan and Bhutan suggested that common antibiotics like ciprofloxacin $(94 \%)$, penicillin $\mathrm{G}(68 \%)$, erythromycin (62\%), tetracycline $(55 \%)$, and azithromycin $(7.7 \%)$ were highly resistance with Neisseria gonorrhoeae pathogens.[51] Another study on antibiotic resistance patterns of common gram negative pathogens isolate from urinary tract infection (UTI) in E St. Paul's Hospital Millennium Medical College in Ethiopia revealed that the resistance rate of E.coli pathogens was high with common antibiotics like tetracycline, ampicillin, amoxicillin and nalidixic acid. Similarly, these pathogens were low resistance with Nitrofurantoin, Gentamycin and TrimethoprimSulfamethoxazole.[52] Study on nasopharynx/throat specimens isolate from 145 children under age 1-5 years in Vietnam suggested that S.pneumoniae and $\mathrm{H}$. influenza pathogens resistant to tetracycline $(88 \%$ and $32 \%$ respectively), trimethoprim/sulphonamide (32\% and $44 \%$ ), and chloramphenicol (25\% and 24\%). S. pneumoniae pathogen was resistant to erythromycin $23 \%$ and $\mathrm{H}$. influenza isolate pathogen was resistant to ampicillin $18 \%$. [53] Study on antibiotic resistance pattern of common pathogens isolates from single episode urinary tract infection (UTI) from 175 children below 14 years in Oman revealed that E. coli and Klebsiellapneumoniae was resistant with cotrimoxazole, amoxicillin + Clavulanic acid, Cefuroxime and nitrofurantoin. [54]

\section{Situation of Antimicrobial Resistance in Nepalese Community}

In the context of Nepalese community studies suggested $64 \%$ E. coli were resistant to fluoroquinolones and $38 \%$ were resistant to thirdgeneration cephalosporins however K. pneumonia exhibited resistance to third-generation cephalosporins of $48 \%$, while no resistance to carbapenems. [55]

Co-trimoxazole was highly resistance to $S$. pneumoniae in 2002 and slightly decrease the resistance rate in 2008. Similarly, the increasing trend of resistance to penicillin with highest in 2007, followed by ampicillin, erythromycin, ciprofloxacin and ceftriaxone. [56] Study on bacterial etiology of septicaemia among children in a tertiary care center of central Nepal revealed that coagulase negative staphylococcus and staphylococcus aureus pathogens were resistant with methicillin whereas amikacin was found to be very good alternative antibiotic for gram positive as well as gram negative with very minor resistance to it.[57] Amoxicillin-clavulanic acid and ciprofloxacin were resistance with $\mathrm{E}$. coli however few percentage rate of imipenem antibiotic was resistance with E. coli. [58] and Amikacin was found to be most sensitive antimicrobial followed by nitrofurantoin and gentamicin. ampicillin showed the higher percentage of resistant, compared to other antimicrobials. [59] Another study suggested individual's overall exposure to antibiotics and antibiotic-resistant bacteria has an equal or greater impact on an individual's carriage of antibiotic-resistant bacteria than does direct consumption of antibiotic. [60]

\section{Problems of Antibiotic Uses}

Sah et al www.apjhs.com
Asian Pacific Journal of Health Sciences, 2019;6(3):56-64

Page 60 
In inappropriate or over use of any antibiotics may contribute to

Adverse drug reaction: Any noxious and unintended response to medicine when given at normal dose in course of treatment of disease. [61] Infant and child have a high risk of adverse drug reaction because their organism is not matured Therefore they are unable to metabolize some drugs. For example, newborn cannot metabolize and eliminate chloramphenicol antibiotic that can lead to development of gray baby syndrome Antibiotic resistance, use of antibiotic in low dose may result in treatment failures. More prescribing, administrating and misuse of antibiotics can lead to increase in the health cost, antibiotic resistance and poor health outcome. e.g. Use of antibiotic in viral infection. Use of antibiotic in common cold, runny nose etc.

\section{Initiative to combat antibiotic resistance in Nepal}

In appropriate and irrational use of antibiotic can lead as antibiotic resistance. It is also one of the another region to develop resistance i.e patient do not adherence with therapy or poor quality of antibiotic are use. Hence, Nepal government seeks to reduce the health risk due to antibiotic resistance by collaborating with partners. These five pillars have been preferred on the basis of WHO resolution and Nepal's commitments in different forums. Improve awareness and understanding of AMR through effective communication, education and training. Strengthen the knowledge and evidence base through research and surveillance. Reduce the incidence of infection through effective hygiene and infection prevention measures. Optimize the use of antimicrobial medicines in human and animal health. Develop the economic case for sustainable investment that takes account of the needs of all countries, as well as the need for investment in new medicines, diagnostic tools, vaccines and other interventions. [62,63,64]

\section{CONCLUSION}

Studies from developed and developing countries suggested the increase in antibiotic utilization. Antibiotics were frequently dispensed without prescription in developing countries. Studies from developing countries also indicate the use of antibiotic as self-medication. Likewise, studies from developed and developing countries suggested high rate of antibiotic resistance. Hence it is high time for action against misused of antibiotic.

\section{REFERENCE}

1. WHO. Promoting rational use of medicines: core component. WHO Policy Perspectives on Medicines September. 2002: 1-6.

2. WHO. WHO Global strategy for containment of antimicrobial resistance. Switzerland. 2001

3. Wise, R., T. Hart. Antimicrobial resistance. Is a major threat to public health.BMJ. 1998: 317(7159): 609-10.

4. World Health Organization. Introduction to drug utilization research. Oslo, Norway. 2003

5. Al-Azzam.SI, Al-Husein.BA, Alzoubi.F, Masadeh.MM, Al-Horani.MAS.Self-medication with antibiotic in Jordanian population. International Journal of Occupational Medicine and Environmental Health.2007; 20(4):373 - 380

6. Mohanna.M. Self-medication with Antibiotic in Children in Sana'a City, Yemen. Oman Medical Journal.2010; 25(1):1

7. Awad. A, Eltayeb. I, Matowe. L Thalib. L. Selfmedication with antibiotics and antimalarials in the community of Khartoum State, Sudan. J Pharm PharmSci.2005;8:326-31.

8. Parimi N, Pinto Pereira LM, Prabhakar P. Caregivers' practices, knowledge and beliefs of antibiotics in paediatric upper respiratory tract infections in Trinidad and Tobago: a crosssectional study. BMC FamPract. 2004; 5:28.

9. Sturm. AW, van der Pol. R, Smits. AJ, van Hellemondt. FM, Mouton. SW, Jamil. B, et al. Over-the-counter availability of antimicrobial agents, self-medication and patterns of resistance in Karachi, Pakistan. J Antimicrob Chemother. 1997; 39:543-7.

10. Vaananen. MH, Pietila. K, Airaksinen. M. Selfmedication with antibiotic — does it really happen in Europe? Health Polic. 2006; 77: 16671.

11. Contopoulos-Ioannidis. DG, Koliofoti. ID, Koutroumpa. IC, Giannakakis. IA, Ioannidis. JPA. Pathways for inappropriate dispensing of antibiotics for rhinosinusitis: a randomized trial. Clin Infect Dis. 2001; 33:76-82.

12. Mitsi. G, Jelastopulu. E, Basiaris. H. Patterns of antibiotic use among adults and parents in the community: a questionnaire-based survey in a Greek urban population. Int J Antimicrob Agents. 2005; 25: 439-43.

13. Richman. PB, Garra. G, Eskin. B, Nashed. AH, Cody. R. Oral antibiotic use without consulting a physician: a survey of ED patients. Am J Emerg Med. 2001; 19: 57-60.

14. Abasaeed.A, Vlcek.J, Abuelkhair.M, Kubena. A. Self-medication with antibiotics by the 
community of Abu Dhabi Emirate, United Arab Emirates.J Infect Dev Ctries.2009; 3(7): 491-497.

15. Grigoryan. L, Haaijer-Rysjamp. FM, Burgerhof. JG, Mechtler. R, Deschepper. R, TambicAndrasevic.A. Self-medication with antimicrobial drugs in Europe. Emerg Infect Dis.2006; 12: 452-9.

16. Nyambayar. KH, Nakamura..K, Ohnishi. M, Nakajima. R, Urnaa.V, Takano.T. Purchase of Antimicrobials in Retail Pharmacies When a Prescription is Not Required. J Rural Med. 2012; 7(2): 51-58;

17. Haak H. Pharmaceuticals in two Brazilian villages: lay practices and perceptions. SocSci Med. 1988; 27(12): 1415-27.

18. Kroeger. A. Anthropological and socio-medical health care research in developing countries. SocSci Med. 1983; 17(3): 147-61.

19. Quick. JD, Foreman. PF. Pharmaceuticals and financing for health in the '90s: strategic perspective for Asia and Near East:USAID 1989.

20. Wirtz.VJ, Dreser. A, Gonzales.R. Trends in antibiotic utilization in eight Latin American countries, 1997-2007. Rev Panam Salud Publica. 2010; 27(3):1

21. Bronzwaer.S LAM, Cars. O, Buchholz.U, Molstad.S, Goettsch.W et.al The relationship between antimicrobial use and antimicrobial resistance in Europe. Emerging Infectious Diseases.2002; 8(3):278-282

22. Versporten.A, Bolokhovets.D, Ghazaryan.L, Abilova.V, Pyshnik.G, Spasojevi.T et.al, Antibiotic use in eastern Europe: a cross national database study in coordination with the WHO Regional office for Europe. Lancet inect Dis. 2014:01-07 www. The lancet.com/ infection. http://dx.doi.org/10.1016/S1473-3099(14)70071$\underline{4}$

23. Al-Bakri.AG, Bustanji.Y, Yousef. AM. Community consumption of antibacterial drugs within the Jordanian population: sources, patterns and appropriateness. International Journal of Antimicrobial Agents. 2005:389-395

24. Kehinde.OO, Ogunnowo.BE. Pattern of antibiotic use by the public in an urban slum community in Lagos, Nigeria

25. Clarence. YS, Edrin. YO, Odeh. EN. Pattern of antibiotic usage by adult populations in the city of Benin, Nigeria. Scientific Research and Essay. 2008; 3(3): 81-85.

26. Duong.DV, Binns. CW, Le. TV. Availability of antibiotics as over-the-counter drugs in pharmacies: a threat to public health in Vietnam.
Tropical Medicine and International Health. 1997; 2 (12): 1133-1139.

27. Lansang. MA, Juban. N, Macaehor. L, Kunin.C. A drugstore survey of antibiotic use in a rural community in the Philippines; 1991. http://www.researchgate. net/ publication /242180103.

28. Belkina.T, Warafi. AA, Eltom. EH, Tadjieva. N, Kubena. A, Vlcek. J. Antibiotic use and knowledge in the community of Yemen, Saudi Arabia, and Uzbekistan. J Infect Dev Ctries. 2014; 8(4) : 424-429

29. Sayeed. MA, Iqbal. N, Ali Md S, Rahman. Md M, Islam. Md R, Jakaria. Md. Survey of antibiotic practices in Chittagomg city Bangladesh; Bangladesh Pharmaceutical Journal.2015; 18(2): 174-178.

30. Shet. A, Sundaresan. S, Forsberg. BC. Pharmacy based dispensing of antimicrobial agents without prescription in India: appropriateness and cost burden in the private sector. Antimicrobial resistance and infections control. 2015; 4:55

31. Kotwani.A, Holloway.K. Trends in antibiotic use among outpatients in New Delhi, India. BMC Infectious Diseases. 2011; 11:9

32. Khan.SJ, Khan. AS, Shah. N. Self-Medication with Antibiotics in Urban Areas of Peshawar. Gomal Journal of Medical Sciences. 2011; 9(1):1.

33. Widayati.A, Suryawati.S, Crespigny.CD, Hiller. JE. Self-medication with antibiotics in Yogyakarta City Indonesia: a cross sectional population-based survey. BMC Research Notes.2011; 4:491. http://www.biomedcentral. com/1756-0500/4/491

34. Mainous.AG, Diaz.VA, Carnemolla.M. A community intervention to decrease antibiotic used for self-medication among Latino Adults. Annals of family medicine.2009; 7: 520-526.

35. Gonzalez-Lopez.JR, Rodriguez-Gazquez.M.de lo A, Lomas-Campos.M de las M. Self-medication in adult Latin American immigrants in Seville. Acta Paul Enferm. 2012;25 (2) :75-81.

36. Berzanskyte.A, Valinteliene.R, HaaijerRuskamp.FM, Gurevicius.R, Grigoryan.L. Selfmedication with antibiotics in Lithuania. International Journal of Occupational Medicine and Environmental Health.2006; 19(4) : 246 - 53.

37. Raz.R, Edelstein.H, Grigoryan.L, HaaijerRuskamp.FM. Self-Medication with Antibiotics by a Population in Northern Israel. IMAJ. 2005; 7:722-725.

38. Ngu.RC, Feteh.VF, Kika.BT, Nerice.EK, Ayeah.CM et.al, Prevalence and Determinants of Antibiotic Self-Medication among Adult Patients 
with Respiratory Tract Infections in the Mboppi Baptist Hospital, Douala, Cameroon: A CrossSectional Study. Diseases. 2018; 6:49; 1:9, www.mdpi.com/journal/diseases.

39. Okyay.RA, Erdoğan.A, Self-medication practices and rational; drug use habits among university students: a cross sectional study from Kahramanmaras, Turkey. Okyay and Erdogan. $2017 ; 1-14$

40. Muras.M, Krajewski.J,Nocun.M, GodyckiCwirko.M. A survey of patient behaviours and beliefs regarding antibiotic self-medication for respiratory tract infections in Poland. Arch Med Sci. 2013; 9 (5): 854-857.

41. Pant. N, Sagtani. RA, Pradhan. M, Bhattarai. A, Sagtani. A. Self-medication with antibiotics among dental student of Kathmandu-prevalence and practice. Nepal Med Coll J.2015; 17(1-2): 47-53.

42. Sah. AK, Jha.RK, Shah.DK. Self-medication with antibiotic among nursing students of Nepal. International Journal of Pharma Sciences and Research (IJPSR). 2016; 7(11):427-430.

43. Shankar.PR, Partha.P, Shenoy.N Self-medication and non-doctor prescription practices in Pokhara valley, Western Nepal: a questionnaire-based study. BMC Family Practice. 2002; 3. http://www.biomedcentral.com/1471-2296/3/17.

44. Zawahi.S, Lekamwasam.SmAslani.P Antibiotic dispensing practice in Sri Lankan community pharmacies: A simulated client study. Research in Social and Administrative Pharmacy. 2018. https://doi.org/10.1016/j.sapharm.2018.07.019,(in press, corrected proof)

45. Chang.J, Ye.D, Lv.B, Jiang.M, Zhu.S, Yan.K, et.al, Sale of antibiotics without a prescription at community pharmacies in urban China: a multicentre cross-sectional survey. J AntimicrobChemother. 2017; 72: 1235-1242

46. Ansari.M Evaluation of the most commonly dispensed antibiotics among the pharmacies located in and around National Medical College Teaching Hospital, Birgunj, Nepal. Indian Journal of Pharmacy Practice.2013; 6(3):62-64.

47. Nepal Health Facility Survey 2015, Final Report; Ministry of Health, Nepal; New ERA, Nepal; Nepal Health Sector Support Program (NHSSP); and ICF. 2017. Nepal Health Facility Survey 2015. Kathmandu, Nepal: Ministry of Health, Nepal.

48. Ministry of Health and population (available on www.mohp.gov.np accessed on 01th October 2015
49. Harper.I, Brhlikova.P, Subedi.MS, Bhattarai.S, Basu.S et.al, Drug procurement in Nepal. 2007. The centre for international public health policy. University of Edinburgh.

50. WHO. "The role of pharmacist in encouraging prudent use of antibiotic and averting antimicrobial resistance: a review of policy and experience". Europe, 2014:01-23

51. Sethi.S,Golparian.D, Bala.M, Dorji.D,Ibrahim.M, Jabeen.K, Antimicrobial susceptibility and genetic characteristics of Neisseria gonorrhoeae isolates from India, Pakistan and Bhutan in 20072011. BMC infectious Diseases.2013;13(35):0108

52. Mamuye.Y, Antibiotic Resistance Patterns of Common Gram-negative Uropathogens in St. Paul's Hospital Millennium Medical College. Ethiop J Health Sci.2016; 26(2):93-100.

53. Larsson.M, Kronvall. G, Chuc.NTK, Karlsson.I, Lager.F, Hanh.HD et al. Antibiotic medication and bacterial resistance to antibiotics: a survey of children in a Vietnamese community. Tropical Medical and International community. 2000;5(10):711-721

54. Sharef.SW, Naggari.ME,Nabhani.DA, Sawai.AA, Muharrmi.ZA,Elnour.I, Incicence of antibiotics resistace among uropathogens in Omani children presenting with a single episode of urinary tract infections. Journal of infection and Public Health.2015;8:458-465.

55. WHO. Antimicrobial resistance: global report on surveillance. Geneva, Switzerland; 2014.

56. Shakya.G, Adhikari.BR, Ten years surveillance of antimicrobial resistance pattern of Streptococcus Pneumoniae in Nepal. African Journal of Microbiology Research. 2012; 6(20): 4233-4238,

57. Ansari.S, Nepal.HP, Gautam.R, Shrestha.S, Neopane.P, Rimal.B, et.al, Childhood septicaemia in Nepal: Documenting the bacterial etiology and its susceptibility to antibiotics. International Journal of Microbiology.2014;0106.

58. Ansari.S, Nepal.HP, Gautam.R, Shrestha.S, Neopane.P, Gurung.G et.al, Community acquired multi drug resistant clinical isolates of Escherichia coli in a tertiary care center of Nepal. Antimicrobial Resistance and Infection Control. 2015; 4(15):01-08

59. Hapa.P, Parajuli.K, Poudel.A, Thapa.A, Manandhar.B, Laudari.D, et. Al, causative agents and susceptibility of antimicrobials among suspected females with urinary tract infection in 
tertiary care hospitals of western, Nepal. Journal of Chitwan Medical College. 2013;3(4):16-19

60. Walson.JL, Marshall.B, Pokhrel.BM, Kafle.KK, Levy.SB, Carriage of Antibiotic-Resistant Fecal Bacteria in Nepal Reflects Proximity to Kathmandu. The Journal of Infectious Diseases. 2001; 184:1163-9.

61. Schatz.SN, Weber.RJ, Hultgren.KE, Timpe Behnen. EM, Barros.MC. Adverse Drug Reactions. PSAP.2015:05-26.
62. National antimicrobial resistance containment action plan Nepal. 2016

63. Kafle.KK, Pokhrel.BM, Antimicrobial resistance at different level of health care services in Nepal. Regional Health Forum.2011; 15(01):1.

64. World Health Organization. World health day; Combat antimicrobial resistance. 2011, http://www.who.int/world-health-day/2011

Conflict of Interest: None

Source of Support: Nil 